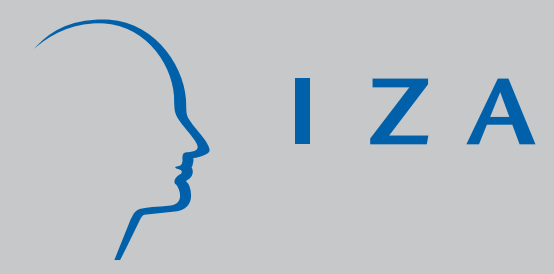

IZA DP No. 3791

Temporary and Persistent Poverty among Ethnic

Minorities and the Majority in Rural China

Björn Gustafsson

Ding Sai

October 2008 


\title{
Temporary and Persistent Poverty among Ethnic Minorities and the Majority in Rural China
}

\author{
Björn Gustafsson \\ University of Gothenburg \\ and IZA \\ Ding Sai \\ Chinese Academy of Social Sciences
}

Discussion Paper No. 3791

October 2008

\author{
IZA \\ P.O. Box 7240 \\ 53072 Bonn \\ Germany \\ Phone: +49-228-3894-0 \\ Fax: +49-228-3894-180 \\ E-mail: iza@iza.org
}

\begin{abstract}
Any opinions expressed here are those of the author(s) and not those of IZA. Research published in this series may include views on policy, but the institute itself takes no institutional policy positions.

The Institute for the Study of Labor (IZA) in Bonn is a local and virtual international research center and a place of communication between science, politics and business. IZA is an independent nonprofit organization supported by Deutsche Post World Net. The center is associated with the University of Bonn and offers a stimulating research environment through its international network, workshops and conferences, data service, project support, research visits and doctoral program. IZA engages in (i) original and internationally competitive research in all fields of labor economics, (ii) development of policy concepts, and (iii) dissemination of research results and concepts to the interested public.
\end{abstract}

IZA Discussion Papers often represent preliminary work and are circulated to encourage discussion. Citation of such a paper should account for its provisional character. A revised version may be available directly from the author. 


\section{ABSTRACT \\ Temporary and Persistent Poverty among Ethnic Minorities and the Majority in Rural China*}

Poverty among ethnic minorities and the majority in rural China for the years 2000, 2001 and 2002 is investigated taking a dynamic view and using a large sample covering 22 provinces. Based on the National Bureau of Statistics' low income line, almost one-third of the ethnic minorities experienced poverty during the three years studied while the corresponding proportion among the ethnic majority was only about half as high. Still, by far most of the poor in rural China belong to the ethnic majority. The relatively high poverty rates for ethnic minorities in rural China are found to be due to higher rates of entry than for the majority, while differences in exit rates across ethnicities are few. To a large extent, ethnic poverty differences can be attributed to differences in location together with temporary and persistent poverty in rural China having a very clear spatial character. Poverty is concentrated to the western region and villages with low average income. Determinants of persistent and temporary poverty in rural China differ due to location as well as household characteristics.

JEL Classification: $\quad 132, \mathrm{~J} 15$

Keywords: China, poverty, ethnic minorities

Corresponding author:

Björn Gustafsson

Department of Social Work

University of Gothenburg

P.O. Box 720

SE 40530 Göteborg

Sweden

E-mail: Bjorn.Gustafsson@socwork.gu.se

\footnotetext{
* A previous version of the paper was presented at the International Conference on Experiences and Challenges in Measuring National Income and Wealth in Transition Economies, September 19-21, 2007, Beijing, China jointly organised by the International Association for Research on Income and Wealth (IARIW) and the National Bureau of Statistics (NBS), China. We wish to thank Wang Sangui, our discussant, and others for useful comments.
} 


\section{Introduction}

Households and their members can experience poverty for one year or over several years, and many policy makers, observers and people affected consider it meaningful to distinguish between temporary and persistent poverty. Poverty of a persistent character is a more severe problem than a shorter experience. Adequate measures for alleviating poverty may vary depending on whether poverty is temporary or persistent.

In the research community there have recently been many efforts to better understand how poverty appears when the accounting period for poverty assessment is extended. For those affected, to what degree is poverty a short-term problem, and to what degree is poverty a problem of long duration? Are experiences of poverty widespread in a society or concentrated to a small minority? Increasing the accounting period when making poverty assessments makes it possible to study duration of poverty as well as mobility into and out of poverty and the forces affecting such movements. Such studies can lead to valuable knowledge on the character of poverty, the causes of people becoming poor, and the causes of people leaving poverty.

It is unusual for statistical authorities to regularly produce and report information on households' and individuals’ poverty experience over more than a one-year period. Reading the Statistical Yearbooks for China and other publications from the National Bureau of Statistics, we have not found examples of reports on poverty duration, poverty mobility or estimates on the incidence of persistent and temporary poverty, or on factors that affect the risk of becoming persistently or temporarily poor. In contrast to this, the data NBS regularly collects makes it possible to obtain and publish such information. This paper aims to illustrate such possibilities and to describe how poverty duration, poverty experience and poverty mobility vary in rural China.

The Chinese population can be divided along many dimensions for analytical purposes. With regard to the level of household income and poverty, location is rather important. Rural inhabitants live much different and often much harder lives than their urban counterparts. Within rural China people living in the western provinces face higher poverty risks than those living in the more developed eastern region where economic reform first took off and where most foreign investments have taken place. The dimension we choose to examine is the ethnic 
minority-majority dimension. Somewhat more than 100 million persons (according to the 2000 Census) belong to one of the 55 officially recognized ethnic minorities. Although not well documented, it is generally perceived that minority persons make up a disproportionally large part of the poverty population in rural China, the region where approximately two-thirds of China's population reside. Our study is most probably the first to investigate differences in poverty experiences and poverty dynamics across the rural majority and minority populations.

Many factors can account for minority people in China being more poverty prone than the majority and for experiencing poverty dynamics that are different from those of the majority. For example, in terms of stock of physical and human capital, adult minority persons are on average educated for shorter periods than majority persons. There are demographic differences as well. Many minorities are not subject to birth restrictions as severe as those for the Han majority, therefore household size among minority households tends to be larger.

Another reason for poverty differences between minorities and majorities stems from the fact that some minorities differ from the majority by appearance, language and habits. Such circumstances serve as markers and lead to the risk of discrimination from potential employers or customers. In this line of thinking, the behavior of the majority is the root cause of minority people being more poverty prone than the majority. Another explanation for a higher risk of poverty among minority persons might also be traced to the behavior and preferences of the minority persons themselves. Occasionally one can hear the opinion that minorities place less value on economic activity and do not strive to grasp economic opportunities with the same intensity as people belonging to the ethnic majority.

While there are thus many potential explanations for why minority persons in China are at greater risk of becoming (and possibly staying) poor than the majority, in this paper we focus on still another aspect; one that can be considered fundamental. Due to historical reasons, which include barriers for migration, China's minority population has a spatial distribution which differs from the majority population. Most minority persons in China live in the rural west, concentrated to villages with low average household income. As discussed above, the rural west is also the region of China that is lagging behind the rest of the country in all aspects and where households are at greater risk of being poor than households living elsewhere. We therefore concentrate on space as a reason for differences in poverty between the majority and the minority in rural China. 
In the Chinese literature, many authors have written about poverty in China and some have focused on ethic minorities. Examples include Zhu (2005) whose rich field work in Aba Autonomous Prefecture in rural Sichuan studied Tibetan and Qiang ethnic groups. Another example is Song et al (2003) who studied South Xinjiang. Still another example is Du and Cai (2005) who use rural published data of NBS to review the stages of poverty reduction in rural China, concluding that the nature of poverty in rural China has changed. However, these studies do not compare minorities with majorities, nor do they use data with income measured for more than one period. However, in academic literature in English, we are not the first to study poverty dynamics in rural China. Several papers have been written based on microdata collected by NBS in the four province level units Guangdong, Guangxi, Guizhou and Yunnan for the period 1985 to 1990 from approximately 10000 households (or less), see for example Jalan and Ravallion, (1998) (1999) and (2000). McCulloch and Calandrino (2003) followed 3311 households from 1991 to 1995 to study poverty dynamics in Sichuan. In our study we follow 9074 households living in 22 of China's rural provinces over the period 2000, 2001 and 2002. ${ }^{2}$ The main difference in our work compared to previous studies on poverty dynamics in rural China, is that we focus on the differences between ethnic minorities and the majority.

The rest of the paper is laid out as follows: In the next section the data and some key assumptions are presented. The evolution of poverty during the period under study is shown in Section 3. Results on experiences of poverty and movements in and out of poverty are found in Section 4. Section 5 contains a multivariate analysis of factors affecting temporary and persistent poverty. The paper ends with a concluding section.

\section{Data and poverty line}

Data for this study is provided by the rural household survey for 2002 collected by the China Household Income Project (CHIP). The project was assisted by the General Team of Rural Surveys at the National Bureau of Statistics (NSB) that conducted the fieldwork in early 2003.

\footnotetext{
${ }^{2}$ Our data thus provides wider coverage than previous studies of poverty dynamics in rural China and refers to more recent years. While our study concerns income over three years, however, previous studies were able to follow single households over six or five years.
} 
The questionnaires were designed by the project team to meet the needs of research. ${ }^{3}$

The sample was drawn from the large sample used by NBS in its annual household survey covering around 67000 households. This sample is selected in a multi-stage procedure to be representative at the province level and each province statistical bureau is responsible for samples at the village level. At the village level a probability sample of ten households is selected. The rural households are asked to keep detailed records of their expenditures as well as provide information on their income. A large number of assistant enumerators aid the households in keeping good accounts and in checking the information. ${ }^{4}$

For the research project a sample of 9200 households composed of 37969 individuals were sampled from the larger sample used by NBS. This sample covers 22 provinces or provincial level units of China: Beijing, Hebei, Shanxi, Liaoning, Jilin, Jiangsu, Zhejiang, Anhui, Jiangxi, Shandong, Henan, Hubei, Hunan, Guangdong, Guanxi, Chongqing, Sichuan, Guizhou, Yunnan, Shaanxi, Gansu and Xinjiang. The sampled households live in 961 villages located in 120 different counties. Information on village characteristics were obtained in a special questionnaire directed to cadres.

Many questions in the household questionnaire refer to the situation in 2002, and several studies have been conducted focusing on these circumstances. ${ }^{5}$ Some studies have used the information on household income to study poverty in rural China. One example is Khan (2008) who investigated the evolution of rural poverty between 1995 and 2002, finding rapid decreases all over the country. Such an evolution differed greatly from the experience for the period 1988 to 1995, when despite rapid economic growth, poverty changed but little.

The 2002 rural survey includes information on household income for years before 2002 that to our knowledge have not been previously used for analysis. Based on information collected earlier from the responding households, NBS provided information on household income and number of household members for each of the years 1998, 1999, 2000, 2001, in addition to

\footnotetext{
${ }^{3}$ For more details on the survey see Li et al (2008).

${ }^{4}$ The sample procedure of NBS is not formally documented. We cannot rule out the possibility that some households living in remote locations have a smaller probability of being included in the sample. Such a possible problem can be more severe for ethnic minorities than for the majority. For further discussion on NBS rural household surveys see Chen and Ravallion (1996), Bramall (2001), Gustafsson and Li (2006) and Ravallion and Chen (2007).

${ }^{5}$ See for example chapters in Gustafsson, Li and Sicular (2008).
} 
the more detailed information provided for 2002. Another variable collected indicates when the household was first included in the survey. Out of 9198 households that answered this question, 7241 indicated the year 2000, 1343 an earlier year and 309 a later year. Also, requiring information on total income for each year 2000, 2001 and 2002 resulted in a working sample for this study of 9072 households.

When working with this sample we rely on the definition of total income as collected by NBS. This means that total income is the sum of components such as money income, the value of self-subsistence activities used for consumption in the household, and income in kind. It includes private and public transfers (the former typically more important than the latter). Taxes and fees are subtracted. A component that is not included in the NBS variable total income is the imputed rent of owner occupied housing. ${ }^{6}$

When publishing estimates on the extent of poverty in rural China, NBS uses a poverty line which for 2002 was set to 627 Yuan per person and year. For some years now, NBS also publishes estimates on the number and fraction of people under the low income level which for 2002 was set to 869 Yuan per person and year. ${ }^{7}$ We choose to apply the later alternative after a slight adjustment due to mean income in our sample being slightly higher than what is reported by NBS. We therefore set our poverty line at 878 Yuan and person and year for 2002 (after adjusting for CPI at 881 Yuan in 2001 and 875 Yuan in 2000).

In order to investigate the robustness of our results, we performed some sensitivity analyses. We lowered the poverty line to 627 Yuan per person and year which, unsurprisingly, led to lower poverty rates. However, results on differences in poverty experiences and poverty dynamics across minorities and the majority were qualitatively the same. We also investigated to what extent considering differences in provincial inflation rates affects the results, by using

\footnotetext{
${ }^{6}$ Information on imputed rents from owner occupied housing can be derived from the questionnaire for 2002. To ensure comparability across years, we did not include those components in the computations for this paper. Mean per capita income in our work sample is slightly higher than the mean of the same variable reported by NBS (based on a larger sample) in Statistical Yearbook of China. The difference amounts to 4.7 percent in 2000, 3.6 percent in 2001 and 4.7 percent in 2002.

${ }^{7}$ This is a level that approximates the World Bank's poverty line of 1 USD per person and day when applying the conversion factors for PPP that were available until 2008. However, revisions of PPP for China means that the World Bank 1 USD poverty line now can be set at a higher number of Yuan, see Chen and Ravallion (2008). When the World Bank reports poverty incidence for P.R. China, the estimates are based on household consumption, not on income as in this study. In China many low-income households have higher income than consumption, meaning that poverty rates calculated from a fixed poverty line are higher if computed based on consumption rather than on income.
} 
price indices developed by and reported in Brandt and Holz (2006). However, most results are very similar to those reported here and are therefore not shown.

\section{The evolution and profile of poverty in rural China}

/Figure 1 about here/

Based on our assumptions and data we first show how poverty in rural China has developed from 2000 to 2002 by depicting the Cumulative Density Functions in Figure 1. ${ }^{8}$ While the functions are very close to each other at very low income levels, this is not the case for the preferred poverty line of 878 Yuan per person and year or for higher poverty lines. As the curves do not cross for a wide range of levels of the poverty line, many poverty indices will give the same ranking of poverty situations. We can therefore limit the exposition to the head count ratio (the poverty rate) which, as reported in Table 1 (third line from below), for entire rural China decreased from 11.3 percent in 2000 to 10.5 percent in 2001 and 9.7 percent in 2002.

/Table 1 about here/

/Figure 2 and Figure 3 about here/

Not surprisingly, poverty is lowest in the richest eastern region of China and highest in the western in our data, with the middle region in-between; see Figure 2 showing the situation in 2002. During this year the poverty rate in eastern China stood at 4.2 percent, at 7.3 percent in central China and at 14.4 percent in western China. ${ }^{9}$ With this background we inspect the Cumulative Density Functions for the minority and majority populations in 2002 as shown in Figure 3. Poverty is definitively more extensive among the minorities, and for all levels of the

\footnotetext{
${ }^{8}$ The analytical unit in the figure is persons. For a longer perspective of annual changes in poverty in China see Ravallion, and Chen (2007).

${ }^{9}$ The eastern region includes the following province level units in our sample: Beijing, Hebei, Liaoning, Jiangsu, Zhejiang, Shandong, Guangdong.

The central region includes Shanxi, Jilin, Anhui, Jiangxi, Henan, Hubei, Hunan. Finally, the western region includes Guangxi, Chongqing, Sichuan, Guizhou, Yunnan, Shaanxi, Gansu, Xinjiang.
} 
poverty line illustrated in the figure. Our estimate of the poverty rate for the minority population is 15.5 percent in 2002 as compared to 8.7 percent for the majority. Table 1 shows that poverty rates have fallen since 2000 in both populations, a fall that took place between 2000 and 2001 for the majority and between 2001 and 2002 for the minority.

We have thus found that in rural China the poverty risk for the ethnic minority is about twice as high as the risk for the majority. This is similar to what Gustafson and Wei (2000) report based on CHIP for 1988 and 1995. It means that out of five poor people in rural China, one is a minority person and four belong to the Han majority. This picture is in sharp contrast to Bhalla and Qui (2006) who state, based on World Bank (1995),that ethnic minorities make up 40 to 50 percent of the poor in China. Newer similar information is published by the World Bank (2001) and it states that about 40 percent of the "remaining absolute poor" are ethnic minorities. This publication refers to the State Ethnic Affairs Commission for its information, writing that the basis for the estimates is information for autonomous counties and regions (minority areas). This is problematic because of a far from perfect overlap between officially designated minority areas and the minority population. Some officially designated minority areas are actually populated by majority persons; in some areas they form the majority. Further, many majority persons live outside minority areas.

/Figure 4 about here/

Here we take one step further in the analysis and compare poverty among minority persons and majority persons living in the western region of China. This is a crude way of considering location. Figure 4 for 2002 shows an interesting picture of large similarities, as over a relatively wide range of levels for the poverty line there are no differences between the curves for minorities and majorities to comment on. Only for very low poverty lines and the highest poverty line are there some indications of poverty being more extensive among the minority. However, for 2000 and 2001, Table 1 shows somewhat more differences in poverty rates between minority and majority people living in western rural China. It thus seems appropriate to conclude that differences in location between the minority and majority populations of rural China provide the main explanation for higher poverty rates in rural China as a whole.

\section{Experiences of poverty and movements in and out of poverty}


/Table 2 about here/

We now turn to experience of poverty as reported in Table 2 and find that over the three-year period, 17 percent of the rural households have experienced poverty for at least one year. Further, there is large heterogeneity in poverty experience. For slightly more than half of those in the sample who have experienced poverty, theirs is only a one-year experience. Slightly less than one-quarter of all households with poverty experience have spent two years in poverty, but not a third year. Finally, almost one-fourth of the households with poverty experience have spent all three years in poverty and make up 4 percent of the rural households in China.

As expected from poverty rates computed for single years reported in the previous section, poverty experience measured over three subsequent years varies widely across the three regions of rural China. Poverty was experienced by as few as 8 percent of eastern households, but by as many as 29 percent of western households. While only two percent of eastern or central households experienced poverty all three years under study, the corresponding number in western China was 7 percent.

Not surprisingly, poverty experience was more widespread within the ethnic minority population than in the majority; 31 percent compared to 14 percent, respectively. The rate of being poor for three subsequent years is twice as large among the ethnic minority. However, many of the ethnic differences disappear when only observing households living in western China. In fact, the rate of being poor all three years under observation is virtually identical for the minority and the majority, while the numbers reported point towards shorter poverty experience being more frequent for the minority.

\section{/Table 3 about here/}

In Table 3 we report year to year movements in and out of poverty computed as rates of entry (for 2001 and 2002) together with rates of exit (for the same two years). In most cases there are few differences in rates to comment on. For rural China as a whole we find that the rate of entry poverty was 4 percent. Almost half of the households that were poor one year were not poor the next. It is interesting to see that the computed exit rates do not differ significantly 
across the three regions of rural China. Instead it is differences in entry rate that cause yearly poverty rates to be higher in western China. Similar comments can be made when comparing the minority and the majority. China's rural minorities are at greater risk of falling into poverty than the majority. However, once entering poverty, the rate of exit appears to be rather similar for the minority and the majority. Again, when limiting the comparison of the two ethnic categories to the western region of China, not many differences emerge. ${ }^{10}$

Mobility with reference to poverty status between 2001 and 2002 can be further studied by taking into consideration the household's poverty status for 2000. When studying entry and exit we can distinguish between households that were not poor in 2001 nor in 2002, and those who were poor 2001 (but non-poor in 2002). The latter category thus re-enters poverty. In a similar manner we can examine exits for those who were poor in 2001 as well as in 2002 and those who were poor 2001 but non-poor in 2002. The latter category has thus re-exited poverty.

/Table 4 about here/

The information presented in Table 4 shows large differences in entry as well as exit rates conditioned on poverty status the preceding year. While only 3.5 percent of households that were non-poor in 2000 as well as in 2001 entered poverty in 2002, the corresponding number for households that were poor in 2000 but not in 2001 was 18 percent. The risk of re-entering poverty the next year is thus substantial, although most households that exited poverty remain non-poor. Households that entered poverty in 2001 exited poverty at the high rate of 72 percent, but those who remained in poverty in 2000 as well as 2001 had an exit rate of only 35 percent. Thus while most households that enter poverty experience poverty for only one year, it is also true that households that have remained poor for two years typically continue to be poor the third year. These patterns are found for all regions of China. They are also found for the minority/majority categories. Once again in western China there are few differences across ethnicity to draw attention to.

\section{Modeling different poverty experiences}

\footnotetext{
${ }^{10}$ The only exception is that in 2001, but not in 2002, the risk of becoming poor was greater for the minority.
} 
The preceding analysis has shown that for some households, poverty is a brief experience while for others it is long, and that there are households that do not really fit either category. When analyzing our data, some households who appear to be in short-term poverty might in reality be ending a long-term poverty spell during the period of observation. They are left censored. Take the example of a household that was poor in 1998, 1999 and 2000. It will appear as a one-year poor household in our data (as our observation period begins with 2000), although the household's poverty spell was not a one-year experience. Similarly, some households that have entered poverty during the period under study will remain poor for several years; they are right censored.

With this background we choose to proceed as follows when classifying households that have had different poverty experiences: Households that were poor for all years 2000, 2001 and 2002 are classified as "persistently poor”. To this category we also assign households having had a per capita income lower than 2634 (that is, three times the annual poverty line) for the period 2000 to 2002 disregarding whether they have experienced one or two years of nonpoverty. All other households that have experienced poverty at least once during the same three years are labeled temporarily poor.

\section{/Table 5 about here/}

Table 5 reports on rates of temporary poverty, persistently poverty and not-poverty by various breakdowns. In this disaggregation, variation along two variables stands out: education of household head and average village household income. While as few as 1 percent of households headed by a person with professional school or longer were persistently poor, the corresponding percentage for households headed by a person having less than three years of schooling was 10 percent. While less than 1 percent of the households living in a village with average household income in the top quintile experienced persistent poverty, as many as 20 percent of households in the bottom quintile experienced persistent poverty.

In order to better understand how household and location characteristics affect the household's risk of being temporarily and persistently poor, we use multinomial logit analysis. Based on results from previous studies of poverty in rural China, we select explanatory variables. At the household level we measure the following attributes of the head: education, age, party membership and ethnicity. We also include household size and an indicator of the 
household's access to irrigated land. Variables measured at the village level are average per capita income in 1998, dummies indicating at what year the village was electrified (an indicator of path dependency), and dummies for altitude. We include the altitude dummies as conditions for agriculture are likely to be less favorable in the highest situated locations than on the plains; lesser efforts are required to transport goods to markets on the plains and it is easier to access labor markets. Finally, we also include 21 province dummies.

\section{/Table 6 about here/}

Several comments can be made on the estimates reported in Table 6. First: The coefficients for variables measuring the household's size, education of household head and the head being a Communist Party member were estimated with a high z-statistic, but this is not true for age of household head. Second: Turning to the coefficient for the minority dummy we find coefficients with low z-statistics. Third: Coefficients for several village characteristics are estimated with high z-statistics for both states. The highest z-statistics are reported for the negative coefficient for the variable average per capita village income. Coefficients for dummy variables indicating year of electrification (earlier than during the 1990s) are negative and measured with high z-statistics, indicating lower poverty in villages developed earlier. The positive coefficient for the variable indicating mountain altitude is estimated with a high z-statistic. In the last column of Table 6 we report a test of equality for coefficients for persistent and temporary poverty. Several circumstances are found to affect persistent poverty more strongly than temporary poverty according to this criterion - education of household head, household size, average per capita village income, having electricity before 1969 and mountainous location. ${ }^{11}$

\section{/ Table 7 about here/}

Finally in Table 7 we use the estimated model to predict the probability for a household to belong to each of the three states. In the first part of the table we show predictions for a household having disfavorable household and locational characteristics (household A). According to the model, the prediction of being persistently poor is as high as 43 percent and the prediction for being temporarily poor is 33 percent. When changing household

\footnotetext{
${ }^{11}$ The only example of a variable significantly affecting temporary poverty more strongly than persistent poverty is that the village is located in a hilly area.
} 
characteristics, the prediction for being non-poor increases from 24 percent to 46 percent and changing location only increases the probability of being non-poor to 48 alternatively 46 percent. The polar case is household B which possesses favorable household as well as locational characteristics. It has a probability of being non-poor as high as 97 percent, but the prediction decreases to 69 percent if it possesses disfavorable household characteristics, and to 76 percent alternatively 74 percent if it possesses disfavorable locational characteristics (but retains favorable household characteristics)

\section{Conclusions}

In this paper we have contrasted poverty among ethnic minorities and the majority in rural China for the years 2000, 2001 and 2002 taking a dynamic view and using a large sample covering 22 provinces. Based on a poverty line set approximately at the level of the low income line applied by the National Bureau of Statistics of China, we find that the incidence of poverty in rural China is about twice as high for ethnic minorities as it is for the majority. Almost one-third of the ethnic minorities experienced poverty during the three years studied, though by far most of the poor in rural China do not belong to ethnic minority groups.

Several households in rural China experience poverty temporarily, but for others poverty is persistent. We report considerable mobility in and out of the poverty status. Relatively many households that leave the status of being poor return to poverty the next year. Households that recently have fallen into poverty exit poverty at a considerably higher rate than those who have remained in poverty longer. We find that the higher poverty rates among ethnic minorities in rural China compared to the majority are mainly due to higher rates of entry while there are few differences in exit rates across the ethnicities.

Results from different analyses indicate that the ethnic poverty differences in rural China can largely be attributed to differences in location, temporary and persistent poverty in rural China having a very clear spatial character. In rural China, ethnic minorities are concentrated to the less-developed western region where annual poverty rates and poverty experiences measured over a three-year period are more extensive than elsewhere. When controlling for a number of household and location factors there were no strong signs of household ethnicity having an independent effect on poverty status. 
Results from the statistical analysis presented here indicate that in rural China the determinants of persistent and temporary poverty differ in several respects. Some characteristics of the village (i.e., to be situated up in the mountains, to possess a low average household income) are stronger determinants of persistent poverty than of temporary poverty. The same is the case for some variables at the household level (i.e., a large household size, education of household head).

Are there policy conclusions to draw from our results? We believe that our study clearly supports the view that the main causes of ethnic poverty disparities in rural China are spatial. When considering location and selected household characteristics, ethnicity was not found to have much of an independent effect on poverty status. From this follows that the most promising policies for narrowing the poverty disparity between the ethnic majority and the minority should be those promoting growth in low-income villages (that are concentrated to western China) irrespective of the ethnicity of the inhabitant. 


\section{References}

Bhalla, A.S. and Qiu, S (2006) Poverty and Inequality Among Chinese Minorities, London and New York: Routledge (Routledge studies in the Chinese economy).

Bramall, C. (2001) “The Quality of China’s Household Income surveys”, China Quarterly, 167, $689-705$.

Brandt, L., and Holz, C., (2006) "Spatial Price Differences in China: Estimates and Implications”, Economic Development and Cultural Change, 55, 43-86.

Chen, S. and Ravallion, M. (1996) "Data in Transition: Assessing Rural Living Standards in Southern China”, China Economic Review, 7, 23 - 56.

Chen S. and Ravallion, M. (2008) "China is Poorer than we Thought, But No Less Successful in the Fight against Poverty”, World Bank: Policy Research Working Paper 4621.

Du Yang and Cai Fang, "The Transition of the Stages of Poverty Reduction in Rural China", China Rural Survey, No.5, 2-10 (In Chinese).

Gustafsson, B. and Li, S. (2006) "Surveys - Three Ways to Obtain Household Income Data" in Heimer, M. and Thogersen, S. (eds) Doing Fieldwork in China, Copenhagen: NIAS Press.

Gustafsson, B., Li, S and Sicular, T. (Eds) (2008) Inequality and Public Policy in China, Cambridge: Cambridge University Press.

Gustafsson, B. och Wei, Z (2000) "How and Why has Poverty in China Changed? A Study based on Microdata for 1988 and 1995”, China Quarterly, 164, 983 - 1006.

Jalan, J and Ravallion, M. (1998) “Transient Poverty in Post-reform Rural China ”, Journal of Comparative Economics, 26, 338-57.

Jalan, J and Ravallion, M. (1999) "Are the Poor Less Well Insured? Evidence on Vulnerability to Income Risk in Rural China”, Journal of Development Economics, 58, 61-81.

Jalan, J. and Ravallion, M. (2000) “Is Transient Poverty Different? Evidence for Rural China”, Journal of Development Studies, 36, 82-99.

Khan, A. (2008) “Growth, Inequality and Poverty. A Comparative Study of China's Experience in the Periods Before and After the Asian Crisis” in Gustafsson, B., Li, S. and Sicular, T. (eds) (2008) Inequality and Public Policy in China, Cambridge: Cambridge University Press.

Li, S., Luo, C., Wei, Z. and Yue, X., (2008) “Appendix: The 1995 and 2002 Household Surveys: Sampling Methods and Data Description,” in Gustafsson, B., Li, S and Sicular, T. (Eds) (2008) Inequality and Public Policy in China, Cambridge: Cambridge University Press.

McCulloch, N. and Calandrino, M. (2003) "Vulnerability and Chronic Poverty in Rural Sichuan”, World Development, 31, 611-28. 
Ravallion, M. and Chen, S. (2007) “China’s (Uneven) Progress Against Poverty”, Journal of Development Economics, 82, 1 - 42.

Song Lin, Zhang Bo and Wai Jiang-ru, (2003) "On the Representative Poverty Features and Analysis of The Poverty Causes in three South Xinjiang Districts”, Journal of Xinjiang University, Vol. 31, No. 3, 18-22 (In Chinese)

World Bank (1995). Staff Appraisal Report: Southwest Poverty Reduction Project Report No. 13968-CHA, Washington D.C. World Bank 18 May.

World Bank (2001) China. Overcoming Rural Poverty, Washington D.C.

Zhu Ling, (2005) "Economic Determinants of Social Integration----A Survey in Aba Autonomous Prefecture Sichuan Province", Chinese Journal of Population Science, No.2 April 1, 9-14 (In Chinese 


\section{Figure 1}

Cumulative Density Functions for rural China 2000, 2001 and 2002.

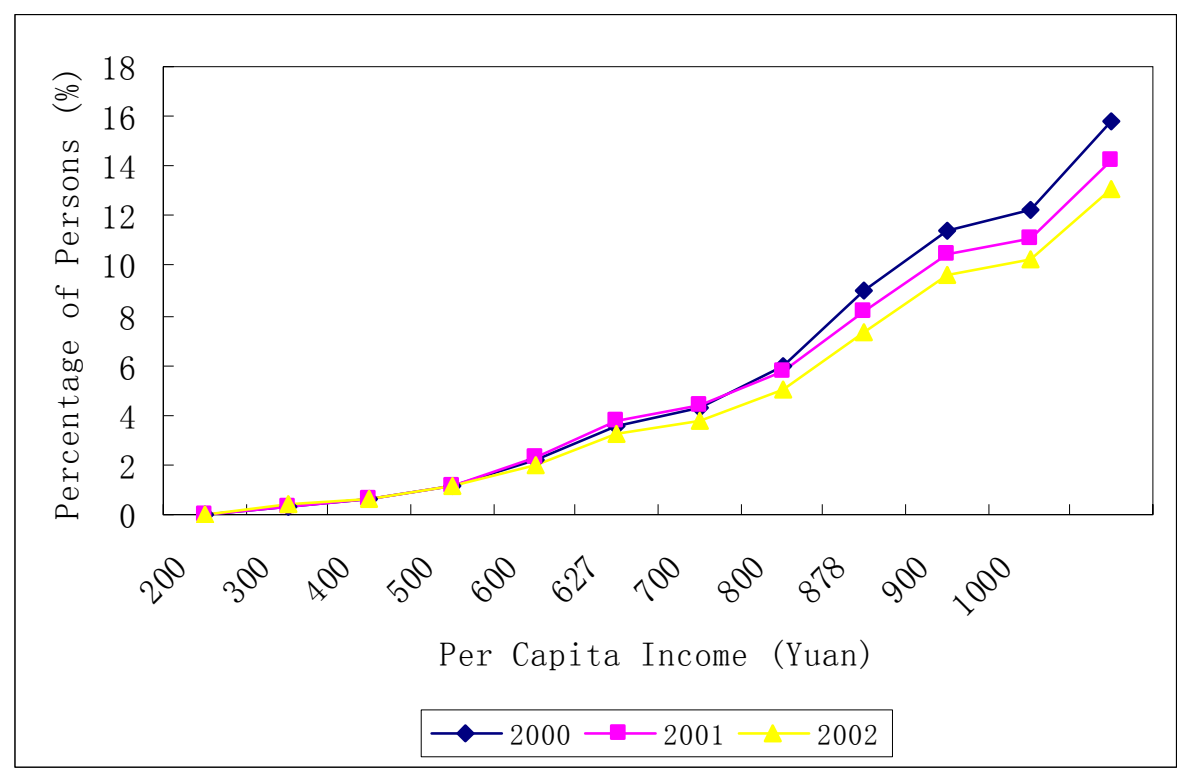

Source : Authors' calculations from China Household Income Project, Rural Survey.

\section{Figure 2}

Cumulative Density Functions for Eastern, Central and Western rural China 2002.

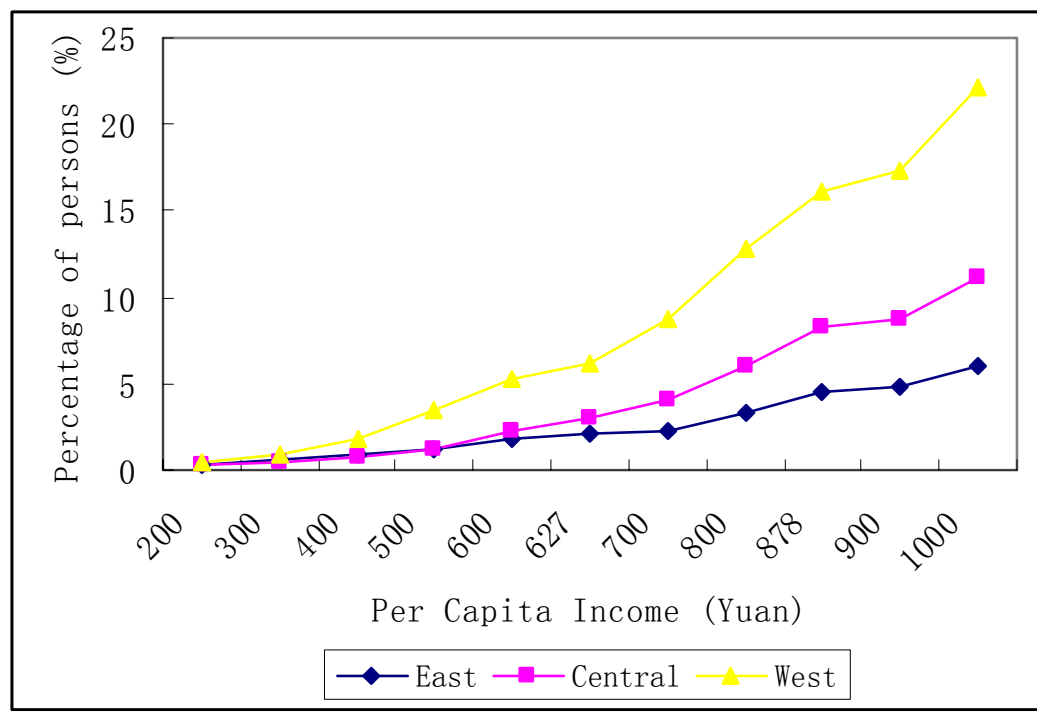

Source : Authors’ calculations from China Household Income Project, Rural Survey. 
Figure 3

Cumulative Density Functions for Ethnic Minorities and the Majority in rural China 2002.

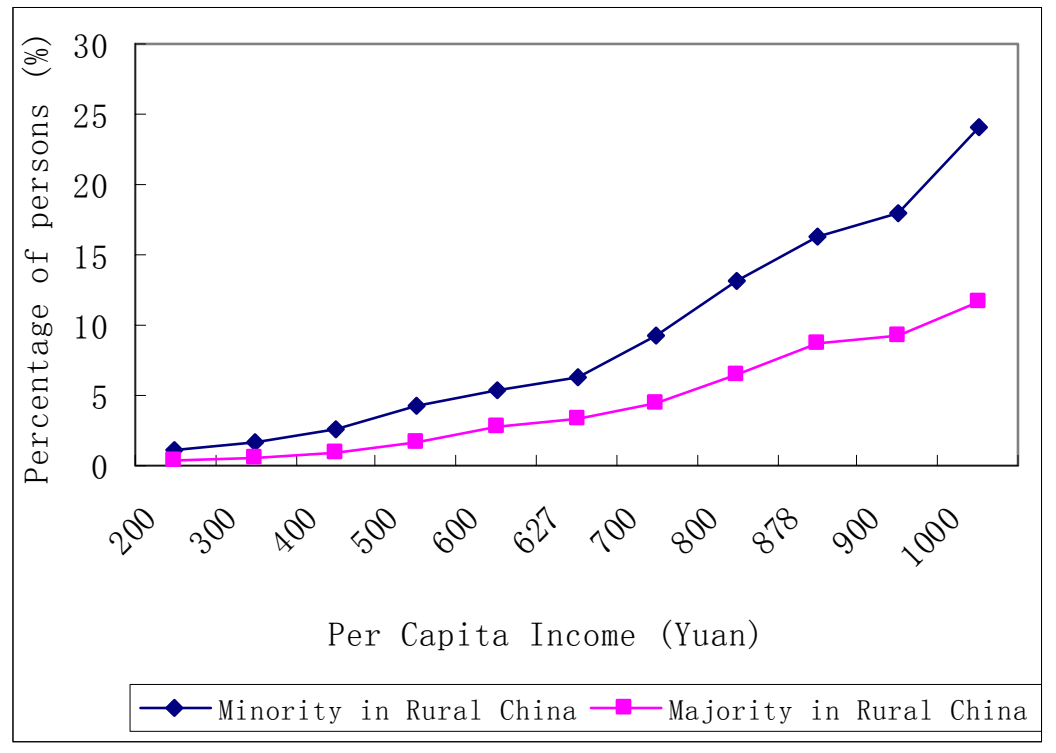

Source : Authors’ calculations from China Household Income Project, Rural Survey.

\section{Figure 4}

Cumulative Density Functions for Ethnic Minorities and the Majority in the western region of rural China 2002.

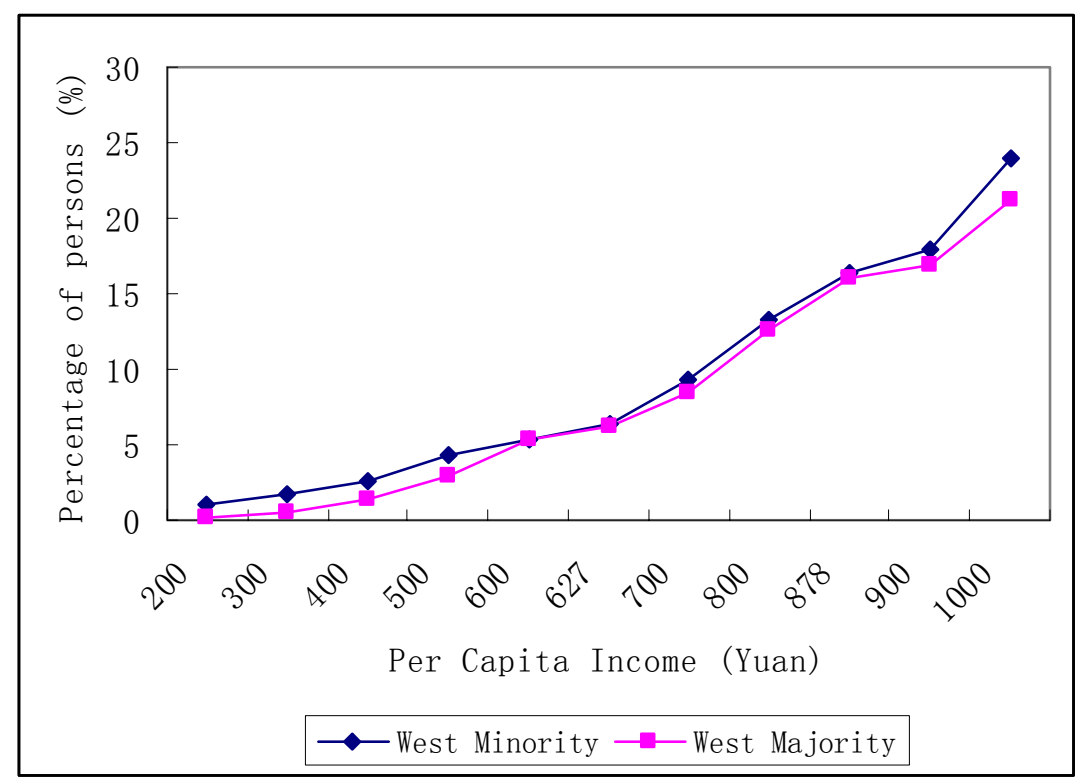

Source : Authors’ calculations from China Household Income Project, Rural Survey. 


\section{Table 1}

Poverty rates in Eastern, Central and Western rural China and for ethnic minorities and the majority 2000 to 2002

Individuals

\begin{tabular}{|c|c|c|c|c|c|c|c|c|}
\hline & & \multicolumn{2}{|l|}{2000} & \multicolumn{2}{|l|}{2001} & \multicolumn{2}{|l|}{2002} & \multirow{2}{*}{$\begin{array}{l}\text { Total } \\
\text { person }\end{array}$} \\
\hline & & $\begin{array}{l}\text { Poverty } \\
\text { rate }\end{array}$ & Persons & $\begin{array}{l}\text { Poverty } \\
\text { rate }\end{array}$ & Persons & $\begin{array}{l}\text { Poverty } \\
\text { rate }\end{array}$ & Persons & \\
\hline East & & 5.41 & 649 & 4.93 & 591 & 4.52 & 542 & 11988 \\
\hline Central & & 8.82 & 1150 & 7.18 & 963 & 8.22 & 1072 & 13034 \\
\hline West & & 19.65 & 2431 & 19.55 & 2419 & 16.16 & 2000 & 12373 \\
\hline West majority & & 18.31 & 1525 & 16.99 & 1415 & 16.09 & 1340 & 8328 \\
\hline West minority & & 22.40 & 906 & 24.82 & 1004 & 16.32 & 660 & 4045 \\
\hline Rural China & & 11.31 & 4230 & 10.53 & 3973 & 9.66 & 3614 & 37395 \\
\hline $\begin{array}{l}\text { Majority in } \\
\text { China }\end{array}$ & rural & 9.75 & 3115 & 8.77 & 2802 & 8.67 & 2767 & 5458 \\
\hline $\begin{array}{l}\text { Minority in } \\
\text { China }\end{array}$ & rural & 20.43 & 1115 & 21.45 & 1171 & 15.52 & 847 & 31937 \\
\hline
\end{tabular}

\section{Households}

\begin{tabular}{|c|c|c|c|c|c|c|c|}
\hline & \multicolumn{2}{|l|}{2000} & \multicolumn{2}{|l|}{2001} & \multicolumn{2}{|l|}{2002} & \multirow{2}{*}{$\begin{array}{l}\text { Total } \\
\text { persons }\end{array}$} \\
\hline & $\begin{array}{l}\text { Poverty } \\
\text { rate }\end{array}$ & $\begin{array}{l}\text { Poverty } \\
\text { household } \\
\text { number }\end{array}$ & $\begin{array}{l}\text { Poverty } \\
\text { rate }\end{array}$ & $\begin{array}{l}\text { Poverty } \\
\text { household } \\
\text { number }\end{array}$ & $\begin{array}{l}\text { Poverty } \\
\text { rate }\end{array}$ & $\begin{array}{l}\text { Poverty } \\
\text { household } \\
\text { number }\end{array}$ & \\
\hline East & 5.17 & 160 & 4.46 & 138 & 4.20 & 130 & 3094 \\
\hline Central & 8.29 & 264 & 6.57 & 209 & 7.32 & 233 & 3183 \\
\hline West & 18.06 & 505 & 16.80 & 470 & 14.41 & 403 & 2797 \\
\hline $\begin{array}{l}\text { West } \\
\text { majority }\end{array}$ & 16.63 & 328 & 14.5 & 286 & 14.15 & 279 & 1972 \\
\hline $\begin{array}{l}\text { West } \\
\text { minority }\end{array}$ & 21.45 & 177 & 22.30 & 184 & 15.03 & 124 & 825 \\
\hline $\begin{array}{l}\text { Rural } \\
\text { China }\end{array}$ & 10.25 & 929 & 9.00 & 817 & 8.44 & 766 & 9074 \\
\hline $\begin{array}{l}\text { Majority in } \\
\text { rural China }\end{array}$ & 8.94 & 705 & 7.54 & 594 & 7.61 & 600 & 7883 \\
\hline $\begin{array}{l}\text { Minority in } \\
\text { rural China }\end{array}$ & 18.81 & 224 & 18.72 & 223 & 13.94 & 166 & 1191 \\
\hline
\end{tabular}

Note: Poverty line: 878 Yuan per year and person.

Source: Authors' calculations from the China Household Income Project, Rural Survey. 
Table 2

Experiences of poverty in Eastern, Central and Western rural China and for ethnic minorities and the majority as investigated over the three years 2000, 2001 and 2003.

\begin{tabular}{|c|c|c|}
\hline & Number in the sample & Percent of total sample \\
\hline Rural China & 9074 & 100 \\
\hline Never poor & 7567 & 83.39 \\
\hline Poor one year & 834 & 9.19 \\
\hline Poor two year & 341 & 3.76 \\
\hline Two spells & 266 & 2.92 \\
\hline One two-year spell & 75 & 0.84 \\
\hline Poor three years & 332 & 3.66 \\
\hline East Region & 3094 & 100 \\
\hline Never poor & 2846 & 91.98 \\
\hline Poor one year & 132 & 4.27 \\
\hline Poor two year & 52 & 1.68 \\
\hline Two spells & 46 & 1.49 \\
\hline One two-year spell & 6 & 0.19 \\
\hline Poor three years & 64 & 2.07 \\
\hline Central Region & 3183 & 100 \\
\hline Never poor & 2726 & 85.64 \\
\hline Poor one year & 285 & 8.95 \\
\hline Poor two years & 95 & 2.98 \\
\hline Two spells & 68 & 2.13 \\
\hline One two-year spell & 27 & 0.85 \\
\hline Poor three years & 77 & 2.42 \\
\hline West Region & 2797 & 100 \\
\hline Never poor & 1995 & 71.33 \\
\hline Poor one year & 417 & 14.91 \\
\hline Poor two years & 194 & 6.94 \\
\hline Two spells & 152 & 5.44 \\
\hline One two-year spell & 42 & 1.50 \\
\hline Poor three years & 191 & 6.83 \\
\hline West region majority & 1972 & 100 \\
\hline Never poor & 1461 & 74.09 \\
\hline Poor one year & 264 & 13.39 \\
\hline Poor two years & 112 & 5.68 \\
\hline Two spells & 85 & 4.31 \\
\hline One two-year spell & 27 & 1.37 \\
\hline Poor three years & 135 & 6.85 \\
\hline West Region minority & 825 & 100 \\
\hline Never poor & 534 & 64.73 \\
\hline Poor one year & 153 & 18.55 \\
\hline Poor two year & 82 & 9.94 \\
\hline Two spells & 67 & 8.12 \\
\hline One two-year spell & 15 & 1.82 \\
\hline Poor three years & 56 & 6.79 \\
\hline Majority in rural China & 7883 & 100 \\
\hline Never poor & 6742 & 85.53 \\
\hline Poor one year & 641 & 8.13 \\
\hline Poor two years & 242 & 3.07 \\
\hline Two spells & 188 & 2.38 \\
\hline
\end{tabular}




\begin{tabular}{lll}
\hline \hline One two-year spell & 54 & 0.69 \\
Poor three years & 258 & 3.27 \\
Minority in rural China & 1191 & 100 \\
Never poor & 825 & 69.27 \\
Poor one year & 193 & 16.20 \\
Poor two years & 99 & 8.31 \\
Two spells & 78 & 6.55 \\
One two-year spell & 21 & 1.76 \\
Poor three years & 74 & 6.21 \\
\hline
\end{tabular}

Note: Poverty line: 878 Yuan per year and person.

Source: Authors' calculations from China Household Income Project, Rural Survey.

Table 3

Rates of entry from and exit into poverty in Eastern, Central and Western rural China and for ethnic minorities and the majority 2001 and 2002.

\begin{tabular}{|c|c|c|}
\hline & \multicolumn{2}{|c|}{ With NBS CPI } \\
\hline & 2001 & 2002 \\
\hline \multicolumn{3}{|l|}{ Rural China } \\
\hline Entry rate & 3.72 & 4.24 \\
\hline Number of observations & 8145 & 8257 \\
\hline Exit rate & 44.67 & 49.08 \\
\hline Number of observations & 929 & 817 \\
\hline \multicolumn{3}{|l|}{ East } \\
\hline Entry rate & 1.47 & 1.73 \\
\hline Number of observations & 2934 & 2956 \\
\hline Exit rate & 40.63 & 42.75 \\
\hline Number of observations & 160 & 138 \\
\hline \multicolumn{3}{|l|}{ Central } \\
\hline Entry rate & 2.77 & 4.67 \\
\hline Number of observations & 2919 & 2974 \\
\hline Exit rate & 51.52 & 55.02 \\
\hline Number of observations & 264 & 209 \\
\hline \multicolumn{3}{|l|}{ West } \\
\hline Entry rate & 7.81 & 6.88 \\
\hline Number of observations & 2292 & 2327 \\
\hline Exit rate & 42.38 & 48.30 \\
\hline Number of observations & 505 & 470 \\
\hline \multicolumn{3}{|l|}{ West majority } \\
\hline Entry rate & 5.66 & 6.94 \\
\hline Number of observations & 1644 & 1686 \\
\hline Exit rate & 41.16 & 43.36 \\
\hline Number of observations & 328 & 286 \\
\hline \multicolumn{3}{|l|}{ West minority } \\
\hline Entry rate & 13.27 & 6.71 \\
\hline Number of observations & 648 & 641 \\
\hline Exit rate & 44.63 & 55.98 \\
\hline Number of observations & 177 & 184 \\
\hline \multicolumn{3}{|l|}{ Majority in rural China } \\
\hline Entry rate & 2.81 & 3.95 \\
\hline
\end{tabular}




\begin{tabular}{lll}
\hline \hline Number of observations & 7178 & 7289 \\
Exit rate & 44.40 & 47.47 \\
Number of observations & 705 & 594 \\
Minority in rural China & & \\
Entry rate & 10.44 & 6.40 \\
Number of observations & 967 & 968 \\
Exit rate & 45.54 & 53.36 \\
Number of observations & 224 & 223 \\
\hline
\end{tabular}

Note: Poverty line: 878 Yuan per year and person.

The number of observations refer to those used for calculating the entry respectively exit rates. Source: Authors’ calculations from China Household Income Project, Rural Survey.

Table 4: Rates on entry into and exit from poverty 2002 conditioned on poverty experience 2000 as well as 2001 in Eastern, Central and Western rural China and for ethnic minorities and the majority.

Number of households used when Percentage Total sample of calculating the relevant rate. this group

\begin{tabular}{|c|c|c|c|}
\hline \multicolumn{4}{|l|}{ Rural China } \\
\hline $\begin{array}{l}\text { Entry rate of households that were poor } \\
\text { in } 2000 \text { and exited poverty in } 2001\end{array}$ & 75 & 18.07 & 415 \\
\hline $\begin{array}{l}\text { Entry of households that were non-poor } \\
\text { in } 2000 \text { and } 2001\end{array}$ & 275 & 3.51 & 7842 \\
\hline $\begin{array}{l}\text { Exit rate of households that were poor in } \\
2000 \text { and } 2001\end{array}$ & 182 & 35.41 & 514 \\
\hline $\begin{array}{l}\text { Exit rate of households that were non- } \\
\text { poor in } 2000 \text { and poor in } 2001\end{array}$ & 219 & 72.28 & 303 \\
\hline \multicolumn{4}{|l|}{ East } \\
\hline $\begin{array}{l}\text { Entry rate of households that were poor } \\
\text { in } 2000 \text { and exited poverty in } 2001\end{array}$ & 6 & 9.23 & 65 \\
\hline $\begin{array}{l}\text { Entry of households that were non-poor } \\
\text { in } 2000 \text { and } 2001\end{array}$ & 45 & 1.56 & 2891 \\
\hline $\begin{array}{l}\text { Exit rate of households that were poor in } \\
2000 \text { and } 2001\end{array}$ & 31 & 32.63 & 95 \\
\hline $\begin{array}{l}\text { Exit rate of households that were non- } \\
\text { poor in } 2000 \text { and poor in } 2001\end{array}$ & 28 & 65.12 & 43 \\
\hline \multicolumn{4}{|l|}{ Central } \\
\hline $\begin{array}{l}\text { Entry rate of households that were poor } \\
\text { in } 2000 \text { and exited poverty in } 2001\end{array}$ & 27 & 19.85 & 136 \\
\hline $\begin{array}{l}\text { Entry of households that were non-poor } \\
\text { in } 2000 \text { and } 2001\end{array}$ & 112 & 3.95 & 2838 \\
\hline $\begin{array}{l}\text { Exit rate of households that were poor in } \\
2000 \text { and } 2001\end{array}$ & 51 & 39.84 & 128 \\
\hline $\begin{array}{l}\text { Exit rate of households that were non- } \\
\text { poor in } 2000 \text { and poor in } 2001\end{array}$ & 64 & 79.01 & 81 \\
\hline \multicolumn{4}{|l|}{ West } \\
\hline $\begin{array}{l}\text { Entry rate of households that were poor } \\
\text { in } 2000 \text { and exited poverty in } 2001\end{array}$ & 42 & 19.36 & 214 \\
\hline $\begin{array}{l}\text { Entry of households that were non-poor } \\
\text { in } 2000 \text { and } 2001\end{array}$ & 118 & 5.58 & 2113 \\
\hline
\end{tabular}




\begin{tabular}{|c|c|c|c|}
\hline $\begin{array}{l}\text { Exit rate of households that were poor in } \\
2000 \text { and } 2001\end{array}$ & 100 & 34.36 & 291 \\
\hline $\begin{array}{l}\text { Exit rate of households that were non- } \\
\text { poor in } 2000 \text { and poor in } 2001\end{array}$ & 127 & 70.95 & 179 \\
\hline \multicolumn{4}{|l|}{ West majority } \\
\hline $\begin{array}{l}\text { Entry rate of households that were poor } \\
\text { in } 2000 \text { and exited poverty in } 2001\end{array}$ & 27 & 20.0 & 135 \\
\hline $\begin{array}{l}\text { Entry of households that were non-poor } \\
\text { in } 2000 \text { and } 2001\end{array}$ & 90 & 5.80 & 1551 \\
\hline $\begin{array}{l}\text { Exit rate of households that were poor in } \\
2000 \text { and } 2001\end{array}$ & 58 & 30.05 & 193 \\
\hline $\begin{array}{l}\text { Exit rate of households that were non- } \\
\text { poor in } 2000 \text { and poor in } 2001\end{array}$ & 66 & 70.97 & 93 \\
\hline \multicolumn{4}{|l|}{ West minority } \\
\hline $\begin{array}{l}\text { Entry rate of households that were poor } \\
\text { in } 2000 \text { and exited poverty in } 2001\end{array}$ & 15 & 18.99 & 79 \\
\hline $\begin{array}{l}\text { Entry of households that were non-poor } \\
\text { in } 2000 \text { and } 2001\end{array}$ & 28 & 4.98 & 562 \\
\hline $\begin{array}{l}\text { Exit rate of households that were poor in } \\
2000 \text { and } 2001\end{array}$ & 42 & 42.86 & 98 \\
\hline $\begin{array}{l}\text { Exit rate of households that were non- } \\
\text { poor in } 2000 \text { and poor in } 2001\end{array}$ & 61 & 70.93 & 86 \\
\hline \multicolumn{4}{|l|}{ Majority in rural China } \\
\hline $\begin{array}{l}\text { Entry rate of households that were poor } \\
\text { in } 2000 \text { and exited poverty in } 2001\end{array}$ & 54 & 17.25 & 313 \\
\hline $\begin{array}{l}\text { Entry of households that were non-poor } \\
\text { in } 2000 \text { and } 2001\end{array}$ & 234 & 3.35 & 6976 \\
\hline $\begin{array}{l}\text { Exit rate of households that were poor in } \\
2000 \text { and } 2001\end{array}$ & 134 & 34.18 & 392 \\
\hline $\begin{array}{l}\text { Exit rate of households that were non- } \\
\text { poor in } 2000 \text { and poor in } 2001\end{array}$ & 148 & 73.27 & 202 \\
\hline \multicolumn{4}{|l|}{ Minority in rural China } \\
\hline $\begin{array}{l}\text { Entry rate of households that were poor } \\
\text { in } 2000 \text { and exited poverty in } 2001\end{array}$ & 21 & 20.59 & 102 \\
\hline $\begin{array}{l}\text { Entry of households that were non-poor } \\
\text { in } 2000 \text { and } 2001\end{array}$ & 41 & 4.73 & 866 \\
\hline $\begin{array}{l}\text { Exit rate of households that were poor in } \\
2000 \text { and } 2001\end{array}$ & 48 & 39.34 & 122 \\
\hline $\begin{array}{l}\text { Exit rate of households that were non- } \\
\text { poor in } 2000 \text { and poor in } 2001\end{array}$ & 71 & 70.30 & 101 \\
\hline
\end{tabular}

Note: Poverty line: 878 Yuan per year and person.

Source: Authors' calculations from China Household Income Project, Rural Survey.

Table 5 Rates of poverty experience, temporary poverty and persistent poverty 2000 to 2002 by household and spatial characteristics. Percent.

\begin{tabular}{|c|c|c|c|c|c|}
\hline & $\begin{array}{l}\text { No poverty } \\
\text { experience }\end{array}$ & $\begin{array}{l}\text { Temporary } \\
\text { poverty }\end{array}$ & $\begin{array}{l}\text { Persistent } \\
\text { poverty }\end{array}$ & Sum & $\begin{array}{l}\text { China as a } \\
\text { whole (poor } \\
\text { and non } \\
\text { poor) } \\
\text { Percent }\end{array}$ \\
\hline $\begin{array}{l}\text { Household } \\
\text { characteristics } \\
\text { Education }\end{array}$ & & & & & \\
\hline
\end{tabular}




\begin{tabular}{|c|c|c|c|c|c|}
\hline \multicolumn{6}{|l|}{ household head } \\
\hline $\begin{array}{l}\text { Professional } \\
\text { school or College } \\
\text { and above }\end{array}$ & 95.12 & 3.66 & 1.22 & 100 & 0.90 \\
\hline $\begin{array}{l}\text { Senior middle } \\
\text { school or Middle } \\
\text { level professional, } \\
\text { technical or } \\
\text { vocational school }\end{array}$ & 88.86 & 6.93 & 4.21 & 100 & 17.84 \\
\hline $\begin{array}{l}\text { Junior middle } \\
\text { school }\end{array}$ & 84.63 & 9.59 & 5.78 & 100 & 48.11 \\
\hline $\begin{array}{l}4 \text { or more years of } \\
\text { elementary school }\end{array}$ & 79.22 & 12.33 & 8.45 & 100 & 25.06 \\
\hline $\begin{array}{l}\text { Below } 3 \text { years } \\
\text { elementary school }\end{array}$ & 76.13 & 13.51 & 10.37 & 100 & 8.09 \\
\hline & & & & & 100 \\
\hline \multicolumn{6}{|l|}{ Age of } \\
\hline Over 60 & 82.53 & 10.36 & 7.11 & 100 & 9.15 \\
\hline $50-60$ & 84.06 & 9.46 & 6.48 & 100 & 28.75 \\
\hline $40-49$ & 84.42 & 9.97 & 5.61 & 100 & 32.83 \\
\hline $30-39$ & 82.21 & 10.52 & 7.27 & 100 & 26.39 \\
\hline Below 30 & 78.46 & 13.85 & 7.69 & 100 & $\begin{array}{l}2.87 \\
100\end{array}$ \\
\hline \multicolumn{6}{|l|}{ Household size } \\
\hline Under 3 persons & 89.45 & 7.08 & 3.47 & 100 & 8.25 \\
\hline 3-5 persons & 84.67 & 9.77 & 5.56 & 100 & 78.95 \\
\hline Over 5 persons & 71.58 & 14.21 & 14.21 & 100 & $\begin{array}{l}12.79 \\
100\end{array}$ \\
\hline \multicolumn{6}{|l|}{ Ethnicity } \\
\hline Majority & 85.53 & 8.82 & 5.65 & 100 & 86.87 \\
\hline Minority & 69.27 & 18.72 & 12.01 & 100 & $\begin{array}{l}13.13 \\
100\end{array}$ \\
\hline \multicolumn{6}{|l|}{ Head party } \\
\hline Member & 88.52 & 7.41 & 4.07 & 100 & 82.10 \\
\hline Non member & 82.27 & 10.72 & 7.01 & 100 & $\begin{array}{l}17.90 \\
100\end{array}$ \\
\hline \multicolumn{6}{|l|}{ 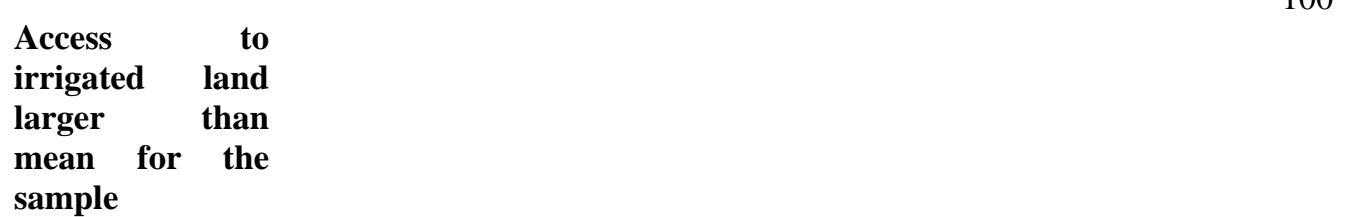 } \\
\hline Yes & 86.85 & 9.20 & 3.94 & 100 & 33.52 \\
\hline No & 81.65 & 10.58 & 7.78 & 100 & $\begin{array}{l}66.48 \\
100\end{array}$ \\
\hline \multicolumn{6}{|l|}{$\begin{array}{l}\text { Location } \\
\text { characteristics }\end{array}$} \\
\hline \multicolumn{6}{|l|}{ Region } \\
\hline East & 91.98 & 4.88 & 3.14 & 100 & 34.10 \\
\hline Central & 85.64 & 9.58 & 4.78 & 100 & 35.08 \\
\hline West & 71.33 & 16.52 & 12.16 & 100 & $\begin{array}{l}30.82 \\
100\end{array}$ \\
\hline \multicolumn{6}{|l|}{$\begin{array}{l}\text { Village access to } \\
\text { electricity }\end{array}$} \\
\hline Before 1969 & 84.91 & 9.04 & 6.05 & 100 & 29.09 \\
\hline $1970-79$ & 84.24 & 9.20 & 6.56 & 100 & 35.02 \\
\hline 1980-89 & 81.84 & 11.63 & 6.53 & 100 & 26.59 \\
\hline 1990-99 & 83.89 & 9.76 & 6.35 & 100 & 7.53 \\
\hline
\end{tabular}




\begin{tabular}{|c|c|c|c|c|c|}
\hline After 1999 & 78.79 & 14.31 & 6.90 & 100 & 1.54 \\
\hline Not yet & 75.34 & 14.79 & 9.86 & 100 & $\begin{array}{l}0.22 \\
100\end{array}$ \\
\hline \multicolumn{6}{|c|}{$\begin{array}{l}\text { Average village } \\
\text { household } \\
\text { income in } 1998\end{array}$} \\
\hline Highest quintile & 97.95 & 1.33 & 0.72 & 100 & 19.96 \\
\hline Fourth quintile & 90.61 & 6.96 & 2.43 & 100 & 19.99 \\
\hline Third quintile & 87.55 & 9.30 & 3.15 & 100 & 19.96 \\
\hline Second quintile & 79.87 & 13.70 & 6.44 & 100 & 20.08 \\
\hline First quintile & 60.87 & 19.37 & 19.67 & 100 & 20.01 \\
\hline \multicolumn{6}{|l|}{ Altitude } \\
\hline Plains & 88.24 & 7.81 & 3.95 & 100 & 46.68 \\
\hline Hills & 86.42 & 9.43 & 4.15 & 100 & 31.15 \\
\hline Mountains & 69.12 & 15.74 & 15.14 & 100 & $\begin{array}{l}22.18 \\
100\end{array}$ \\
\hline \multicolumn{6}{|c|}{$\begin{array}{l}\text { Western region } \\
\text { and ethnicity }\end{array}$} \\
\hline Majority & 74.09 & 14.60 & 11.31 & 100 & 70.50 \\
\hline Minority & 64.73 & 21.09 & 14.18 & 100 & 29.50 \\
\hline
\end{tabular}

Note: Poverty line: 878 Yuan per year and person.

Source: Authors' calculations from China Household Income Project, Rural Survey. 
Table 6 Multinomial Logit analysis of determinants of persistent and temporary poverty as observed during the period 2000 to 2002

\begin{tabular}{|c|c|c|c|c|c|c|}
\hline & $\begin{array}{l}\text { Temporary } \\
\text { poverty }\end{array}$ & & $\begin{array}{l}\text { Persistent } \\
\text { poverty }\end{array}$ & & $\begin{array}{l}\text { Test of equality } \\
\text { of coefficients }\end{array}$ & \\
\hline & Coefficient & $\begin{array}{l}Z \text { Z- } \\
\text { value }\end{array}$ & Coefficient & $\begin{array}{l}\mathrm{Z} \text { - } \\
\text { value }\end{array}$ & T value & $\begin{array}{l}P \\
\text { value }\end{array}$ \\
\hline $\begin{array}{l}\text { Head number of years of } \\
\text { education }\end{array}$ & -0.0833 & -5.01 & -0.0876 & -4.23 & 0.2028 & 0.4027 \\
\hline Head age & -0.0050 & -1.25 & 0.0021 & 0.41 & -0.6699 & 0.5031 \\
\hline Household size & 0.1913 & 6.42 & 0.4035 & 11.02 & -5.8033 & 0 \\
\hline Minority dummy & -0.0344 & -0.28 & -0.0750 & -0.49 & 0.0060 & 0.9952 \\
\hline $\begin{array}{l}\text { Average per capita village } \\
\text { income in } 1998\end{array}$ & -0.0007 & $\begin{array}{l}- \\
10.04\end{array}$ & -0.0012 & - & 6.3070 & 0 \\
\hline Party member dummy & -0.3397 & -3.04 & -0.6280 & -4.23 & 1.0585 & 0.2900 \\
\hline $\begin{array}{l}\text { Have electricity before } \\
1969\end{array}$ & -0.4585 & -3.08 & 1.0290 & -5.37 & 3.3909 & 0.0007 \\
\hline $\begin{array}{ll}\text { Have } & \text { electricity } \\
1969 \sim 1979 & \end{array}$ & -0.5958 & -4.49 & -0.8371 & -5.51 & -1.3287 & 0.1841 \\
\hline $\begin{array}{ll}\text { Have } & \text { electricity } \\
1980 \sim 1989 & \end{array}$ & -0.4404 & -3.54 & -0.8606 & -5.89 & 1.1220 & 0.2621 \\
\hline Mountain area & 0.6220 & 4.39 & 0.6827 & 3.71 & -6.7180 & 0 \\
\hline Hill area & 0.2646 & 2.26 & 0.1216 & 0.71 & 3.9824 & 0.0001 \\
\hline $\begin{array}{l}\text { Average irrigated land } \\
\text { dummy (below is } 0 \text { and } \\
\text { above is } 1 \text { ) } \\
21 \text { Provinces dummies }\end{array}$ & 0.0810 & 0.77 & -0.4309 & -2.75 & 4.3690 & 0 \\
\hline Constants & -1.8793 & -4.42 & -1.0607 & -2.42 & & \\
\hline Pseudo R2 & 0.1852 & & & & & \\
\hline Number of observations & 8913 & & & & & \\
\hline
\end{tabular}

Note: unit of analysis is the household.

The omitted group is non-poor. Persistent poverty refers to a person whose per capita income below $878+881.5+874.5=2634$ for three years; temporary poverty refers to a person whose per capita income is above 2634 but has been poor in any one of the three years.

The omitted province is Gansu.

Source: Authors’ calculations from China Household Income Project, Rural Survey. 
Table 7:

Predicted probabilities for being persistently poor, temporarily poor and non poor.

\begin{tabular}{llll}
\hline & $\begin{array}{l}\text { Persistent } \\
\text { poverty }\end{array}$ & $\begin{array}{l}\text { Temporary } \\
\text { poverty }\end{array}$ & $\begin{array}{l}\text { Non } \\
\text { poverty }\end{array}$ \\
\hline $\begin{array}{l}\text { Probability of category A } \\
\begin{array}{l}\text { Long education, small household, much irrigated land, and } \\
\text { party member }\end{array}\end{array}$ & $\mathbf{4 3}$ & $\mathbf{3 3}$ & $\mathbf{2 4}$ \\
$\begin{array}{l}\text { Highest quintile of average per capita income and living on } \\
\text { the plains }\end{array}$ & 41 & 21 & 35 \\
$\begin{array}{l}\text { Highest quintile of average per capita income, living on the } \\
\text { plains and possessing early access to electricity }\end{array}$ & 38 & 16 & 46 \\
$\begin{array}{l}\text { Probability of category B } \\
\begin{array}{l}\text { Short education, big household, less irrigated land, and non } \\
\text { party member }\end{array}\end{array}$ & $\mathbf{9 7}$ & $\mathbf{2 0}$ & $\mathbf{0 . 3}$ \\
$\begin{array}{l}\text { Lowest quintile of average per capita income and living on } \\
\text { mountain }\end{array}$ & 76 & 8 & 20 \\
\hline $\begin{array}{l}\text { Lowest quintile of average per capita income, living on } \\
\text { mountain and possessing late access to electricity }\end{array}$ & 74 & 8 & 16 \\
\hline
\end{tabular}

Source: Table 6

Category A: persistent poverty person: age $=55$, education year $=0$, located in poorest village of per capita village income, non-party member, majority, household size is 5 , electricity in 1999, irrigated land is below average value, lives in Henan province.

Category B: non-poor person: age $=39$, education year $=14$, located in richest village of per capita village income, party member, majority, household size is 3, electricity before 1969, irrigated land is above average value, lives in Beijing. 


\section{Appendix}

Household and individual characteristics by ethnicities

(Persons) Percent

\begin{tabular}{|c|c|c|c|c|}
\hline & Minorities & Majorities & $\begin{array}{l}\text { Minorities in } \\
\text { western } \\
\text { China }\end{array}$ & $\begin{array}{l}\text { Majority in } \\
\text { western } \\
\text { China }\end{array}$ \\
\hline \multirow{2}{*}{\multicolumn{5}{|c|}{$\begin{array}{l}\text { Household } \\
\text { characteristics } \\
\text { Education } \\
\text { household head }\end{array}$}} \\
\hline & & & & \\
\hline $\begin{array}{l}\text { Professional school } \\
\text { or College and above }\end{array}$ & 0.42 & 0.98 & 0.36 & 0.76 \\
\hline Senior middle school & 12.34 & 18.66 & 8.37 & 14.63 \\
\hline $\begin{array}{l}\text { or Middle level } \\
\text { professional, } \\
\text { technical } \\
\text { vocational school }\end{array}$ & & & & \\
\hline Junior middle school & 41.14 & 49.16 & 38.30 & 45.82 \\
\hline $\begin{array}{l}4 \text { or more years of } \\
\text { elementary school }\end{array}$ & 34.84 & 23.58 & 37.45 & 28.59 \\
\hline $\begin{array}{l}\text { Below } 3 \text { years } \\
\text { elementary school }\end{array}$ & 11.26 & 7.61 & 15.52 & 10.20 \\
\hline $\begin{array}{l}\text { Age of Household } \\
\text { head }\end{array}$ & & & & \\
\hline Over 60 & 9.66 & 9.07 & 9.94 & 8.01 \\
\hline $50-60$ & 24.94 & 25.16 & 23.52 & 24.54 \\
\hline $40-59$ & 30.48 & 32.97 & 29.21 & 30.88 \\
\hline $30-39$ & 30.65 & 30.15 & 31.88 & 32.76 \\
\hline Under30 & 4.28 & 2.65 & 5.45 & 3.80 \\
\hline \multicolumn{5}{|l|}{ Household size } \\
\hline Under3 persons & 6.80 & 8.47 & 4.85 & 6.49 \\
\hline 3-5 persons & 69.94 & 80.32 & 64.97 & 78.45 \\
\hline Over 5 persons & 23.26 & 11.21 & 30.18 & 15.06 \\
\hline \multicolumn{5}{|l|}{ Head party status } \\
\hline Member & 16.47 & 18.11 & 14.67 & 15.12 \\
\hline Non-member & 83.53 & 81.89 & 85.33 & 84.88 \\
\hline \multicolumn{5}{|l|}{$\begin{array}{l}\text { Access to irrigated } \\
\text { land larger than } \\
\text { mean for the sample }\end{array}$} \\
\hline Yes & 35.18 & 33.27 & 42.18 & 20.79 \\
\hline No & 64.82 & 66.73 & 57.82 & 79.21 \\
\hline \multicolumn{5}{|l|}{$\begin{array}{l}\text { Location } \\
\text { characteristics }\end{array}$} \\
\hline \multicolumn{5}{|l|}{ Region } \\
\hline East & 20.07 & 36.22 & & \\
\hline Central & 10.66 & 38.77 & & \\
\hline West & 69.27 & 25.02 & & \\
\hline $\begin{array}{l}\text { Village access to } \\
\text { electricity }\end{array}$ & & & & \\
\hline Before 1969 & 18.81 & 30.65 & 9.82 & 12.58 \\
\hline $1970-79$ & 33.75 & 35.22 & 29.58 & 29.16 \\
\hline
\end{tabular}




\begin{tabular}{lllll}
\hline 1980-89 & 30.23 & 26.04 & 36.97 & 39.55 \\
1990-99 & 13.27 & 6.66 & 17.94 & 14.50 \\
After 1999 & 2.27 & 1.43 & 3.27 & 4.21 \\
Not yet & 1.68 & 0 & 2.42 & 0 \\
& & & & \\
Average village & & & & \\
household income in & & & & \\
1998 & & 21.59 & 1.21 & 1.52 \\
$\begin{array}{l}\text { Highest quintile } \\
\text { Fourth quintile }\end{array}$ & 9.15 & 21.47 & 2.42 & 13.89 \\
$\begin{array}{l}\text { Third quintile } \\
\text { Second quintile }\end{array}$ & 10.24 & 21.45 & 7.88 & 20.03 \\
First quintile & 10.08 & 18.86 & 36.12 & 24.90 \\
& 42.13 & 16.62 & 52.36 & 39.66 \\
Altitude & & & & \\
Plains & & & & \\
Hills & 35.00 & 48.43 & 36.61 & 28.78 \\
Mountains & 15.34 & 33.52 & 13.88 & 38.31 \\
\hline
\end{tabular}

